Research Article

\title{
Influence of Industry-University Cooperation on Economic Development: A Mathematical Statistical Analysis
}

\author{
Xiaodi Xu, ${ }^{1}$ Yongfeng $\mathrm{Zhu} \mathbb{D}^{2},{ }^{2}$ Liuyang $X u,{ }^{2}$ and Zilong Wang ${ }^{2}$ \\ ${ }^{1}$ School of Public Administration, Nanjing Normal University, Nanjing 210023, China \\ ${ }^{2}$ College of Economics and Management, Nanjing University of Aeronautics and Astronautics, Nanjing 211106, China
}

Correspondence should be addressed to Yongfeng Zhu; zhuyongfeng@nuaa.edu.cn

Received 5 October 2021; Accepted 15 December 2021; Published 30 December 2021

Academic Editor: Yong Aaron Tan

Copyright (c) 2021 Xiaodi Xu et al. This is an open access article distributed under the Creative Commons Attribution License, which permits unrestricted use, distribution, and reproduction in any medium, provided the original work is properly cited.

Technical innovation is an important means to achieve sustainable development. Industry-university cooperation is a new form of technological innovation. Most of the existing researches on industry-university cooperation focus on the analysis of industryuniversity cooperation models, but there are few researches on the examination of the relationship between industry-university cooperation and economic development. Using the spatial autocorrelation and spatial measurement model, the relationship between China's industry-university cooperation and economic development was empirically investigated. The results indicate that, first, the nighttime light data could be used as a proxy variable for GDP data to characterize China's economic development. Second, industry-university cooperation had a positive effect on China's economic development. Third, industry-university cooperation affected China's economic development through technological innovation.

\section{Introduction}

Coming into knowledge economy era, resources and environment are increasingly restricting economic development [1]. Technological innovation is gradually becoming the primary driving force for social development [2]. According to World Bank statistics, China's R\&D investment scale increased from USD 4.866 billion in 1996 to USD 259.560 billion in 2017, with an average annual growth rate of $21.16 \%$ (see Figure 1). The number of $\mathrm{R} \& \mathrm{D}$ personnel in China increased nearly threefold from 533,100 in 1996 to $1,578,800$ in 2015. Accordingly, the number of patent applications in China rapidly rose by more than 107-fold from 11.628 thousand in 1996 to 1245.709 thousand in 2017.

According to the endogenous economic theory, technological innovation, as one of the endogenous driving forces of economic growth, mainly comes from enterprises, universities, and scientific research institutions [3]. Industry-university cooperation highlights the linkage role of enterprises in the process of knowledge production and application [4]. Besides, industry-university cooperation also helps universities and research institutions commercialize their innovations [5]. China's 19th National Congress has proposed that China needs to establish a system of technological innovation that is enterprise-oriented, market-oriented, and deeply integrated between industry, universities, and research institutes [6]. Therefore, industry-university cooperation will be one of the trends of China's science and technology development in the future. It is useful to note that industry-university cooperation has received wide attention, while existing literature has almost entirely neglected the relationships between industry-university cooperation and economic growth. The purpose of this study is to examine whether industry-university cooperation can promote economic development using the nighttime light data.

Most of the existing research on economic development is based on official statistics GDP data. However, the quality of China's official statistics is increasingly being questioned by researchers. For example, Movshuk [7] argues that Chinese officials exaggerate growth figures because of political pressure and the use of outdated statistical methods. Meanwhile, the nighttime light data (DMSP/OLS data) has received extensive attention from researchers. The DMSP/ 


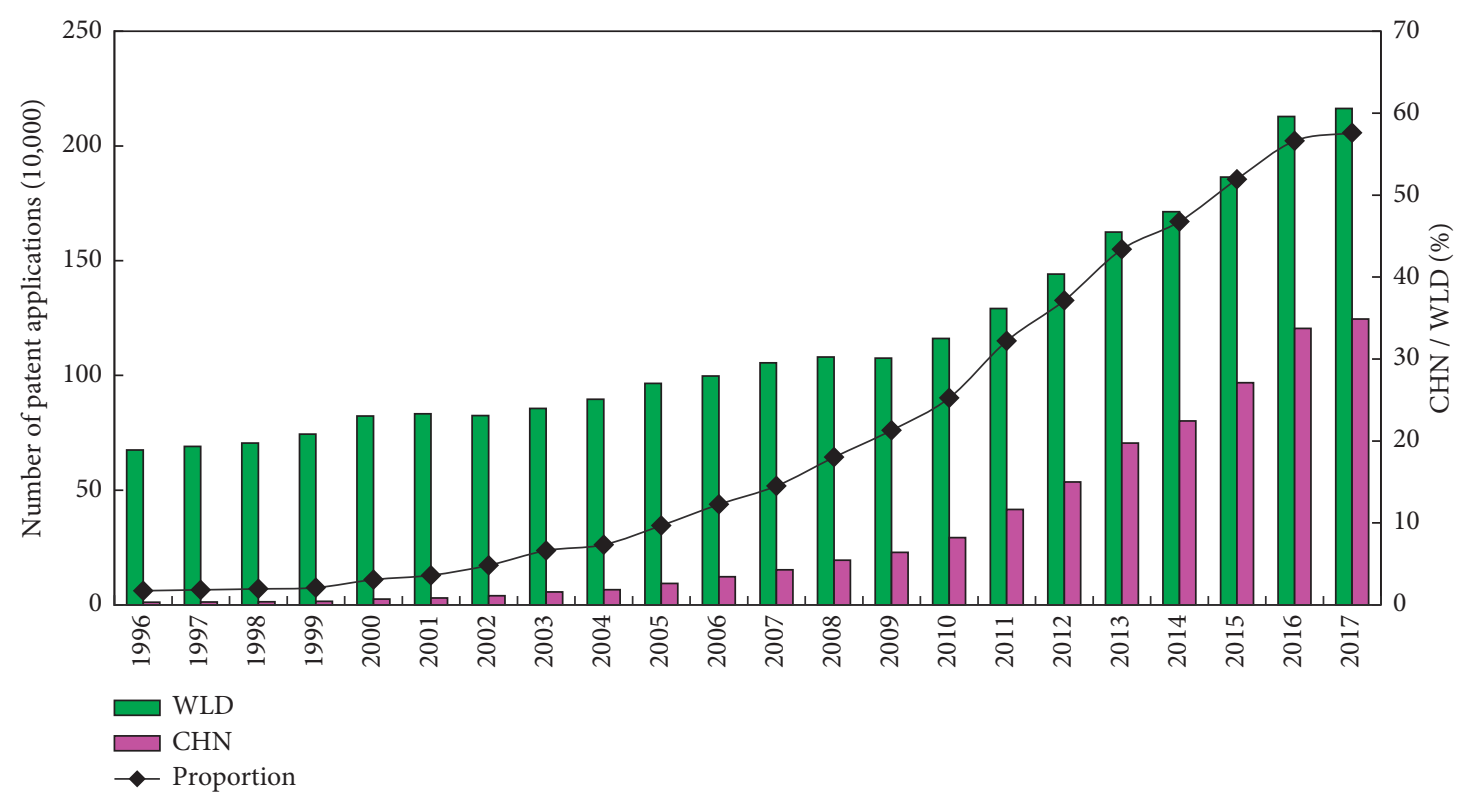

Figure 1: Number of patent applications in China and the world from 1996 to 2017.

OLS data provided by the National Oceanic and Atmospheric Administration (NOAA) is based on meteorological satellites, which makes up for the shortcomings of manual statistics to some extent.

The contributions of this study are as follows. First, using the econometric model, this study investigates the relationship between GDP data and DMSP/OLS data, which may provide new evidence for DMSP/OLS data agent GDP data. Second, this study uses a spatial econometric model to test the relationship between industry-university cooperation and economic development, which may enrich the literature on technological innovation. Third, this study includes technological innovation when discussing the impact of industry-university cooperation on economic development and empirically examines whether industryuniversity cooperation affects economic development through technological innovation.

\section{Literature Review}

2.1. DMSP/OLS Data and Economic Development. Existing researches on DMSP/OLS data focus on economic development, carbon emissions, PM 2.5 emission, urbanization level, and population size [8-10]. Previous studies have confirmed that DMSP/OLS data is associated with socio-economic activities. For example, using DMSP/OLS data, Bennett and Smith [11] estimated and monitored the socioeconomic activities in Russia and China from 1992 to 2012, and they believed that there is a close relationship between nighttime light and social economy. Zhao et al. [12] utilized DMSP/OLS data to investigate the relationship between net primary production and GDP in China, and they found that net primary production has declined in areas where GDP has increased. Propastin and Kappas [13] used DMSP/OLS data to monitor socioeconomic parameters in Kazakhstan, and they confirmed that DMSP-OLS data is an effective tool for monitoring the spatial and temporal changes of socioeconomic parameters. Zhu et al. [14] argued that the integration of DMSP-OLS and NPP-VIIRS data can simulate long-term spatiotemporal GDP dynamics. Li et al. [15] analyzed regional economic development based on time-series DMSP/OLS nighttime data, and they found that it is feasible to use DMSP/OLS to convert GDP data. Using the ecological footprint and DMSP/OLS data, Jin et al. [16] investigated the relationship between ecological efficiency and the economic agglomeration in China.

\subsection{Industry-University Cooperation and Regional Economic} Growth. The endogenous economic theory proposed that technological innovation is one of the driving forces of economic growth. Enterprises, universities, and research institutes are the main sources of technological innovation. Industry-university cooperation refers to the cooperation between enterprises and universities in technological innovation [17]. Industry-university cooperation is essentially a combination of university knowledge production and the knowledge application in enterprise. $\mathrm{Xu}$ and Jin [18] suggested that the cooperation among government, industry, and university in a region can significantly promote the growth of the regional economy. Taking Malaysia as an example, Hamdan et al. [19] found that the university-enterprise interaction is conducive to promoting the development of the regional economy. Wu et al. [20] believed that industry-university cooperation has some positive effect on China's economic growth and performance. Lv and Kan [21] took Jiangxi Province as examples to discuss the effect of industry-university cooperation on economic growth, and they found that industry-university cooperation in Jiangxi province can boost the economic growth.

The neoclassical growth theory proposed that the key factors affecting economic growth are labor, capital, and 
technological innovation [22]. Dhrifi [23] found that technological innovation plays an important role in an economy driven by foreign direct investment. Torres-Preciado et al. [24] found that technological innovation has a positive effect on the regional economic growth of Mexico, and technological knowledge has a cross-border diffusion effect. Using the panel data of 30 provinces in China from 2009 to 2017, Song et al. [25] investigated the influences of industry-university cooperation on carbon emissions, and they found that industry-university cooperation can effectively control carbon emissions. The cooperation between enterprises, universities, and research institutions has facilitated the flow of R\&D funds, technology, and talents. Luo et al. [26] suggested that technological innovation plays an important role in keeping the momentum of economic growth. Wei et al. [27] suggested that the cooperation between industry, universities, and research institutes in the region is conducive to promoting the development of scientific and technological innovation.

In summary, there are many studies on industry-university cooperation, technological innovation, and regional economic growth. However, there are few studies on the relationship between industry-university cooperation, technological innovation, and regional economic growth. There are fewer studies using GDP data to analyze the relationship between the three. Thus, this study mainly answers three questions. (1) Can DMSP/OLS data be used as proxy for China's regional economy? (2) Can industryuniversity cooperation promote regional economic development in China? (3) Is technological innovation an intermediary variable between school-enterprise cooperation and economic development?

\section{Methods and Data Sources}

\subsection{Methods}

3.1.1. Correlation Test. Before the empirical analysis, this study first constructed a traditional econometric model to test whether economic development and nighttime light are related. This correlation test is used to demonstrate whether nighttime light can be used as a proxy indicator of economic development. The traditional econometric model can be obtained by

$$
\left\{\begin{array}{l}
\ln G D P_{i t}=\kappa \ln N L_{i t}+c_{i t}+e_{i t}, \\
\ln G D P_{i t}=\kappa \ln N L_{i t}+u_{i}+c_{i t}+e_{i t}, \\
\ln G D P_{i t}=\kappa \ln N L_{i t}+v_{t}+c_{i t}+e_{i t}, \\
\ln G D P_{i t}=\kappa \ln N L_{i t}+u_{i}+v_{t}+c_{i t}+e_{i t},
\end{array}\right.
$$

where GDP it means economic development. $\mathrm{NL}_{i t}$ is nighttime light. $U_{i}$ represents spatial effect. $V_{t}$ means temporal effect. $e_{\mathrm{it}}$ is the error item.

3.1.2. Spatial Econometric Model. The spatial econometric model is based on the traditional econometric model and incorporates geospatial elements so that it can examine whether the industry-university cooperation of one province affects the economic growth of neighboring provinces [28]. The spatial panel lag model (SLM) of industry-university cooperation [1], technological innovation, and economic development is defined by

$\left\{\begin{array}{l}\ln N L_{i t}=\rho \sum_{j=1}^{n} W_{i j} N L_{j t}+\alpha \ln T I_{i t}+\beta \ln \mathrm{IUC}_{i t}+e_{i t}, \\ \ln N L_{i t}=\rho \sum_{j=1}^{n} W_{i j} N L_{j t}+\alpha \ln T I_{i t}+\beta \ln \mathrm{IUC}_{i t}+e_{i t}+u_{i}, \\ \ln N L_{i t}=\rho \sum_{j=1}^{n} W_{i j} N L_{j t}+\alpha \ln T I_{i t}+\beta \ln \mathrm{IUC}_{i t}+e_{i t}+v_{t}, \\ \ln N L_{i t}=\rho \sum_{j=1}^{n} W_{i j} N L_{j t}+\alpha \ln T I_{i t}+\beta \ln \mathrm{IUC}_{i t}+e_{i t}+u_{i}+v_{t}\end{array}\right.$

where $\mathrm{NL}_{\mathrm{it}}, \mathrm{TI}_{\mathrm{it}}$, and $\mathrm{IUC}_{\mathrm{it}}$ represent economic development, technological innovation, and industry-university cooperation, respectively. $\mathrm{CI}_{i t}, \mathrm{LI}_{i t}$, and $\mathrm{FI}_{\mathrm{it}}$ denote capital input, labor input, and foreign investment, respectively. $\operatorname{LnTI}_{i t}{ }^{*} \mathrm{LnIUC} \mathrm{C}_{i t}$ represents the interaction between industry-university cooperation and technological innovation. $\rho$ is the spatial lag coefficient, which indicates the spatial spillover for economic development. $\alpha, \beta, \vartheta, \varphi, \gamma$, and $\omega$ represent the coefficients of $N L_{i t}, T I_{i t}, I U C_{i t}, C I_{i t}, L I_{i t}, F I_{i t}$, and $\operatorname{LnTI}_{i t}{ }^{*} \operatorname{LnIUC} C_{i t}$, respectively. $W_{i t}$ is the spatial weight, which can be obtained by

$$
W_{i j}= \begin{cases}\frac{1}{\left|\overline{Y_{i}}-\overline{Y_{j}}\right|}, & (i \neq j), \\ 0, & (i \neq j),\end{cases}
$$

where $\overline{Y_{i}}=\sum_{t=T_{0}}^{T} Y_{i t} /\left(T-T_{0}\right)$ and $Y_{i t}$ represents the per capita GDP value in year $t$ of province $i$.

When the spatial is dependent on the error item [29], the spatial error model (SEM) for industry-university cooperation, technological innovation, and economic development can be obtained by

$$
\left\{\begin{array}{l}
\ln N L_{i t}=\alpha \ln T I_{i t}+\beta \ln \mathrm{IUC}_{i t}+\lambda \sum_{j=1}^{n} W_{i j} \phi_{j t}+e_{i t}, \\
\ln N L_{i t}=\alpha \ln T I_{i t}+\beta \ln \mathrm{IUC}_{i t}+\lambda \sum_{j=1}^{n} W_{i j} \phi_{j t}+e_{i t}+u_{i} \\
\ln N L_{i t}=\alpha \ln T I_{i t}+\beta \ln \mathrm{IUC}_{i t}+\lambda \sum_{j=1}^{n} W_{i j} \phi_{j t}+e_{i t}+v_{t}, \\
n N L_{i t}=\alpha \ln T I_{i t}+\beta \ln \mathrm{IUC}_{i t}+\lambda \sum_{j=1}^{n} W_{i j} \phi_{j t}+e_{i t}+u_{i}+v_{t}
\end{array},\right.
$$

where $\phi_{i t}$ is the spatial autocorrelation error item, $\lambda$ is the coefficient of spatial autocorrelation error item, and other variables are the same as in (2).

When the spatial is dependent on the explanatory variables and the explained variables [30], the spatial Dubin 
model (SDM) for industry-university cooperation, technological innovation, and economic development can be constructed by

$$
\left\{\begin{array}{l}
\ln \mathrm{NL}_{i t}=\rho \sum_{j=1}^{n} W_{i j} \ln \mathrm{NL}_{j t}+\alpha \ln T I_{i t}+\beta \ln \mathrm{IUC}_{i t}+\alpha^{\prime} \sum_{j=1}^{n} W_{i j} \ln \mathrm{TI}_{j t}+\beta^{\prime} \sum_{j=1}^{n} W_{i j} \ln \mathrm{IUC}_{j t}+e_{i t}, \\
\ln \mathrm{NL}_{i t}=\rho \sum_{j=1}^{n} W_{i j} \ln \mathrm{NL}_{j t}+\alpha \ln T I_{i t}+\beta \ln \mathrm{IUC}_{i t}+\alpha^{\prime} \sum_{j=1}^{n} W_{i j} \ln \mathrm{TI}_{j t}+\beta^{\prime} \sum_{j=1}^{n} W_{i j} \ln \mathrm{IUC}_{j t}+e_{i t}+u_{i}, \\
\ln \mathrm{NL}_{i t}=\rho \sum_{j=1}^{n} W_{i j} \ln \mathrm{NL}_{j t}+\alpha \ln T I_{i t}+\beta \ln \mathrm{IUC}_{i t}+\alpha^{\prime} \sum_{j=1}^{n} W_{i j} \ln \mathrm{TI}_{j t}+\beta^{\prime} \sum_{j=1}^{n} W_{i j} \ln \mathrm{IUC}_{j t}+e_{i t}+v_{t} \\
\ln \mathrm{NL}_{i t}=\rho \sum_{j=1}^{n} W_{i j} \ln \mathrm{NL}_{j t}+\alpha \ln T I_{i t}+\beta \ln \mathrm{IUC}_{i t}+\alpha^{\prime} \sum_{j=1}^{n} W_{i j} \ln _{j t}+\beta^{\prime} \sum_{j=1}^{n} W_{i j} \ln \mathrm{IUC}_{j t}+e_{i t}+u_{i}+v_{t}
\end{array}\right.
$$

where $\alpha, \beta, \vartheta, \varphi, \gamma$, and $\omega$ denote the coefficients of explanatory variables. Other variables are the same as in (2). If $\varphi(\gamma)=0, \rho \neq 0$, SDM can be simplified to SLM; if $\varphi(\gamma)+\lambda \alpha$ $(\beta)=0$, SDM can be simplified to SEM [31].

3.2. Variable Selection. We constructed a panel dataset covering 30 provinces in China during the period of 2001-2013. Economic development was characterized by DMSP/OLS data. The R\&D funds of universities and research institutes come from enterprises as a proxy variable for industry-university cooperation (IUC). The number of granted patents was used as an indicator for technological innovation (TI). In addition, we also considered the four control variables, namely, capital input (CI), labor input (LI), foreign investment (FI), and interaction variable $\left(\operatorname{LnTI}_{\mathrm{it}}{ }^{*} \mathrm{LnIUC}_{\mathrm{it}}\right)$. The GDP was deflated at a constant price in 2001. The depreciation rate of fixed asset investment was $9.36 \%$. The description and data sources for each variable are shown in Table 1.

3.3. DMSP/OLS Data. DMSP/OLS data were collected from meteorological satellites of DMSP [8]. The observed longitude ranges from $180^{\circ} \mathrm{E}$ to $180^{\circ} \mathrm{W}$. The observed latitude ranges from $-65^{\circ}$ to $75^{\circ}$. There are four types of DMSP/OLS data: Average Visible, Stable Lights, Cloud Free Coverages, and Download Average Lights X Pct (https://ngdc.noaa. gov). In this study, the Stable Lights data were selected to characterize nighttime light (see Figure 2), because the Stable Lights data have dealt with the impact of contingency factors, such as forest fires, noise, cloud cover, and aurora, before being released.

\section{Results}

\subsection{Test the Relationship between Nighttime Light Data and GDP Data}

4.1.1. Correlation Test. According to (1), this study used a traditional econometric model to test the correlation between nighttime light data and GDP data. In the traditional econometric model, GDP was set as the dependent variable and nighttime light was set as the independent variable, as shown in Table 2. Models (1) to (4) represent the OLS model under no fixed effect, fixed year, fixed province, and province-year fixed effect, respectively. It can be seen from Table 2 that the $L n N L$ coefficients under different fixed effects were significantly positive. This result indicates that there was a significant positive relationship between nighttime light and GDP.

4.1.2. Robustness Test. We averaged GDP indicator and nighttime light indicator for robustness tests. The per capita GDP was selected to replace the previous GDP. The average regional light intensity (total nighttime light value/grid number in one province) is used to characterize the nighttime light, as shown in Table 3. The coefficients of LnANL ranged from 0.073 to 0.125 , and the $p$ values were less than 0.01 . This finding again demonstrates that nighttime light and GDP were significantly related.

4.1.3. Spatial Autocorrelation Test. Despite some findings for correlation tests, we still performed spatial autocorrelation tests [32] on GDP and nighttime light to examine the relationship between these two. In this study, the spatial weight for spatial autocorrelation model was selected as the Threshold Distance, as shown in Figure 3. The Moran's I of GDP from 2001 to 2013 ranged from 0.178 to 0.186 (all $p$ values were less than 0.05 ), indicating that China's provincial GDP was spatially dependent. The Moran's I of nighttime light in China ranged from 0.104 to 0.118 (all $p$ values were less than 0.05), indicating that nighttime light had a positive spatial correlation. Moreover, the change trend of curve GDP and curve nighttime light is basically the same, showing a downward trend.

In general, for different estimation models and different data processing methods, the correlation coefficients between GDP and nighttime light were greater than 0 and the $p$ values all pass the significance test, indicating that GDP and 
TABle 1: Description and data sources for each variable.

\begin{tabular}{|c|c|c|c|}
\hline Variable & Indicator & Symbol & Data source \\
\hline Economic growth & Nighttime light & NL & https://ngdc.noaa.gov \\
\hline $\begin{array}{l}\text { Industry-university } \\
\text { cooperation }\end{array}$ & $\begin{array}{l}\text { R\&D funds of universities and institutes } \\
\text { come from enterprises }\end{array}$ & IUC & China science and technology statistical yearbook \\
\hline $\begin{array}{l}\text { Technological } \\
\text { innovation }\end{array}$ & Number of granted patents & TI & China science and technology statistical yearbook \\
\hline Capital input & The amount of fixed asset investment & $\mathrm{CI}$ & $\begin{array}{c}\text { China statistical yearbook and compilation of statistics } \\
\text { material of } 60 \text { years of new China }\end{array}$ \\
\hline Labor input & Number of employees & LI & Statistical yearbooks by province \\
\hline Foreign investment & Actually utilized FDI & FI & WIND database \\
\hline
\end{tabular}

nighttime light have a stable positive correlation. Therefore, nighttime light can be used as a proxy variable for GDP. This result is consistent with the findings of $[11,12]$. Therefore, we used DMSP/OLS data to investigate the impact of industry-university cooperation on economic development in the next step.

\subsection{Effects of Industry-University Cooperation on Economic Development}

4.2.1. Panel Unit Root Test. In order to test the stability of the sample, this study used five test models, namely, LLC, Breitung t-stat, IPS, ADF-Fisher, and PP-Fisher, respectively, to conduct unit root tests for nighttime light, industry-university cooperation, and technological innovation. We conducted unit root tests for the level value and the first-order difference value, respectively, as shown in Table 4. The unit root test of the level value shows that the statistical values of each variable have passed the significance test. This result suggests that the level values of industryuniversity cooperation, technological innovation, and nighttime light were all stable. The unit root test of the firstorder difference value shows that the statistical values of each variable were all significantly positive. This result means that the first-order difference of each variable was all stable.

4.2.2. Spatial Econometric Model. The previous spatial autocorrelation test shows that nighttime light is spatially dependent (see Figure 3). Therefore, the spatial location should be considered when investigating the relationship between industry-university cooperation, technological innovation, and nighttime light. Thus, we constructed the spatial econometric model to test the correlation between industry-university cooperation, technological innovation, and nighttime light, as shown in Table 5.

It can be seen from Table 5 that the statistics of the Hausman test all passed the significance test at the $1 \%$ level, suggesting that the spatial econometric model was applicable to fixed effects. The statistics of Wald test and LR test indicate that the SDM model was more suitable for our case than the SLM model and SEM model. Models (9)-(12) represent the SDM model under no fixed effect, provincefixed effect, year-fixed effect, and province-year-fixed effect, respectively. Model (13) added control variables capital input (LnCI), labor input (LnLI), and foreign investment
(LnFI). Model (14) incorporated an interaction between industry-university cooperation and technological innovation (LnIUC $\times$ LnTI)

The LnIUC coefficients of models (9)-(14) were all positive and significant (see Table 5). This result indicates that industry-university cooperation was associated with economic development under different fixed effects. The LnTI coefficients of models (9)-(14) ranged from 0.005 to 0.582 , suggesting that technological innovation could promote economic development. This result is consistent with the findings of Cao et al. [33-35]. The control variables LnCI and LnLI coefficients were positive in models (13)-(14), indicating that increased capital and labor inputs could boost economic growth. This result support the work of Gori and Sodini $[3,36]$. The LnFI coefficients of models (13)-(14) were positive, suggesting that foreign investment could drive economic growth. This result is consistent with the findings of Lo et al. [37]. The coefficient of LnIUC $\times$ LnTI was positive but not significant. This result indicates that there is an interaction between industry-university cooperation and technological innovation, but it is not significant.

4.2.3. Spatial Spillover Effect Analysis. In this section, we decomposed model (11) to calculate the spatial spillover effects of industry-university cooperation and technological innovation. Table 6 reports the results of spillover effect decomposition. The spillover coefficient of LnIUC was -0.475 ( $p \leq 0.001)$, indicating that industry-university cooperation had a negative spillover effect in space. The spillover coefficient of LnTI was $0.247(p \leq 0.05)$, which suggests that technological innovation had a positive spillover effect in space.

4.2.4. Robustness Test. We used GDP data instead of DMSP/ OLS data to reevaluate the spatial econometric model, as shown in Table 7. The LnIUC coefficients of models (15)-(20) were positive and significant, and the LnTI coefficients for models (15)-(20) were positive and significant. This result was consistent with the results reported in $\mathrm{Ta}$ ble 7 . This finding once again demonstrates that industryuniversity cooperation is conducive to regional economic development in China. In addition, this finding also indicates that it is feasible to use DMSP/OLS data as the proxy variable of GDP. 


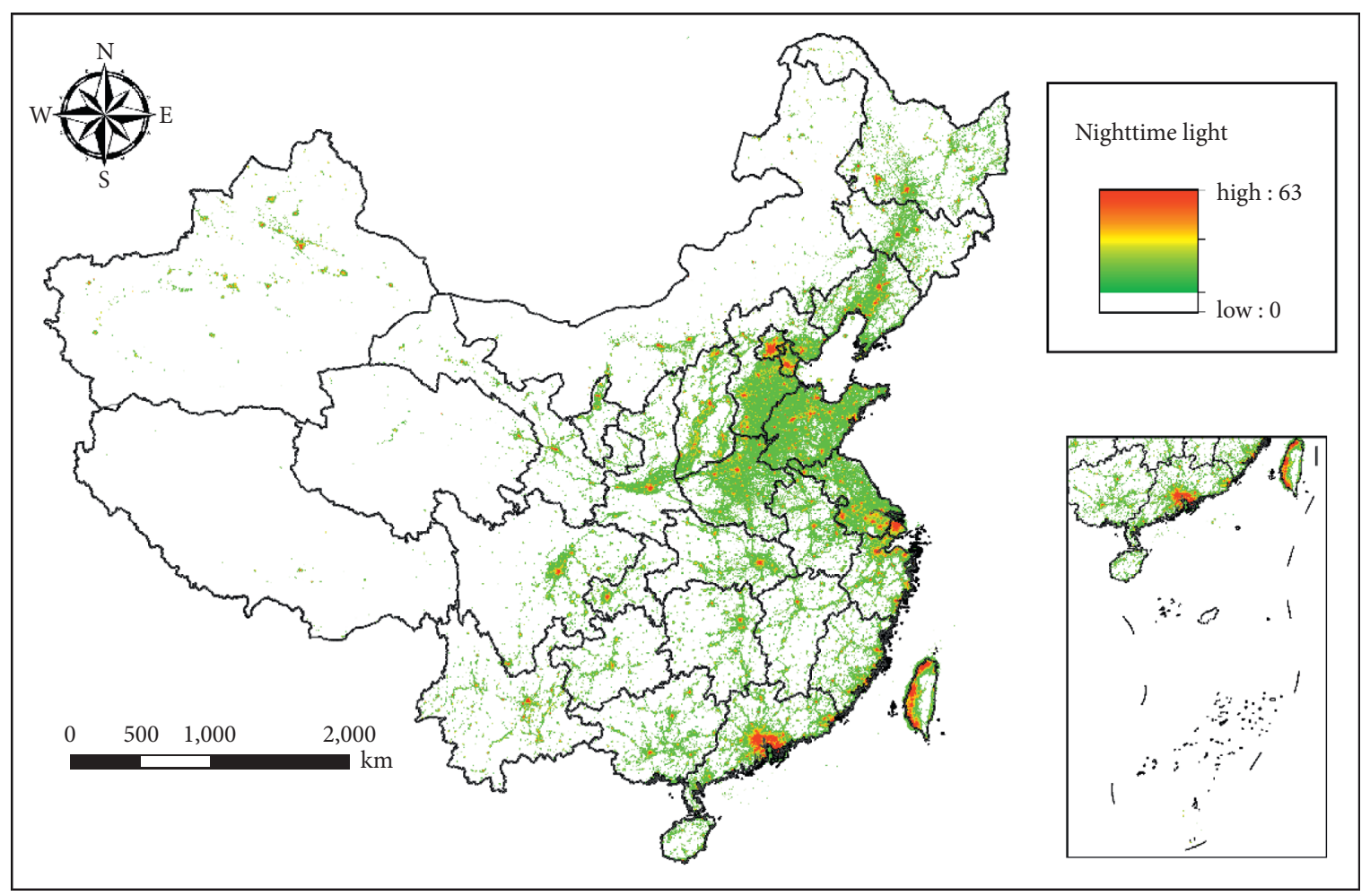

(a)

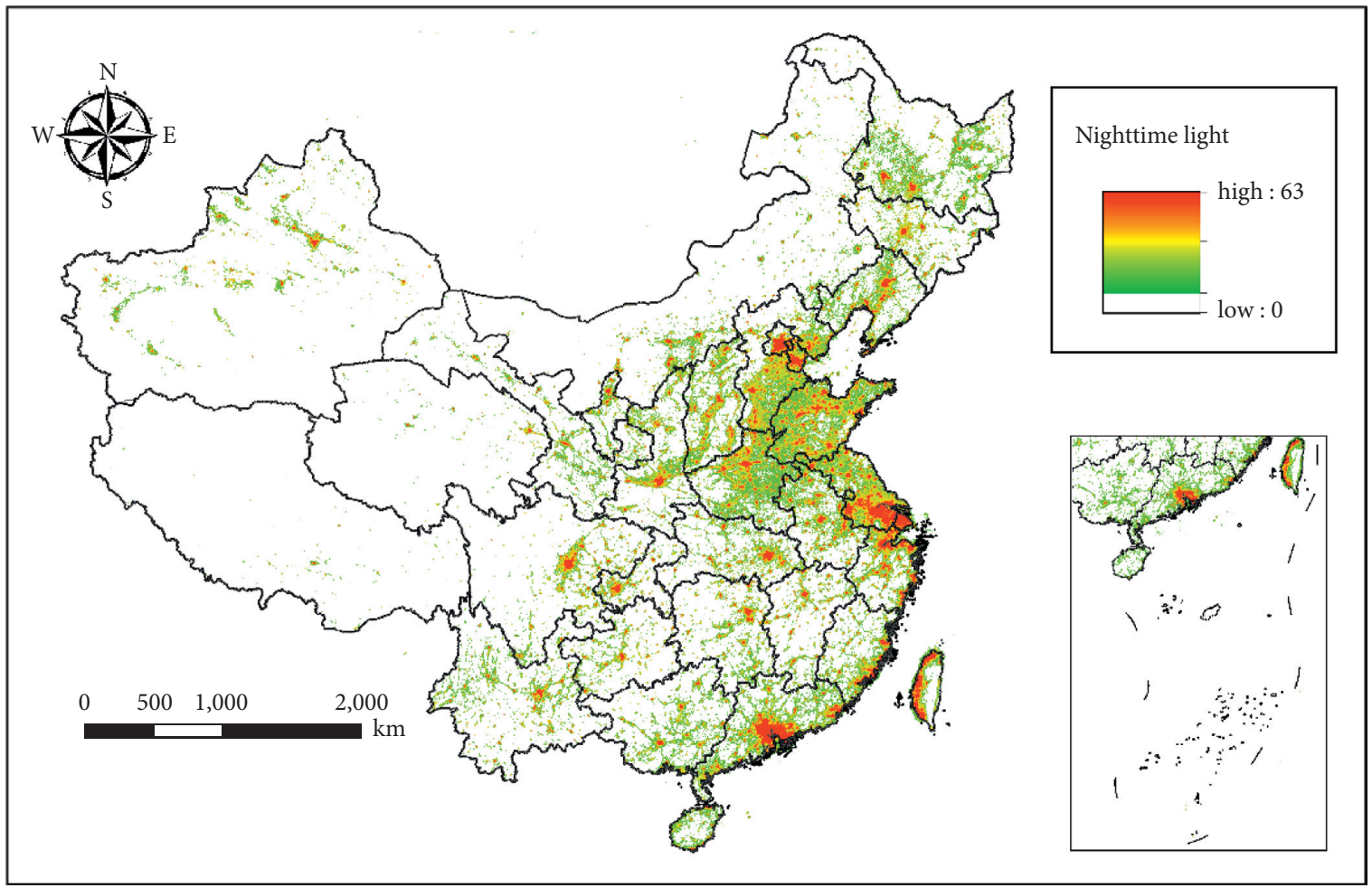

(b)

Figure 2: Spatial patterns of nighttime light in China in 2001 and 2013: (a) 2001 and (b) 2013. 
TABLE 2: Estimated results of correlation coefficient $\kappa$.

\begin{tabular}{lcccc}
\hline Variables & $(1)$ & $(2)$ & $(3)$ & $(4)$ \\
\hline Constant & & $-4.477^{* * *}$ & $-8.225^{* * *}$ & $(-20.381)$ \\
& & $(-9.228)$ & $1.267^{* * *}$ & $(20.032)$ \\
K & $0.650^{* * *}$ & $0.985^{* * *}$ & $(41.757)$ & $\left(5.143^{* * *}\right.$ \\
Province effect & $(265.086)$ & $(27.039)$ & Yes & No \\
Year effect & No & No & Yes & Yes \\
Estimation method & No & FE & 0.963 & FE \\
Adj $R^{2}$ & OLS & 0.718 & 390 & 390 \\
Obs & 0.695 & 390 & & 390 \\
\hline
\end{tabular}

Note. $t$-statistics in parenthesis. ${ }^{* * *} p$ value is less than 0.001 .

TABLE 3: Results of the robustness tests.

\begin{tabular}{lcccc}
\hline Variables & $(5)$ & $(6)$ & $(7)$ & $(8)$ \\
\hline Constant & & $1.742^{* * *}$ & $1.773^{* * *}$ & $(39.598)$ \\
& & $(31.375)$ & $0.073^{* * *}$ & $(39.108)$ \\
K & $0.125^{* * *}$ & $0.083^{* * *}$ & $(17.405)$ & $\left(171^{* * *}\right.$ \\
Province effect & $(13.872)$ & $(16.576)$ & Yes & No \\
Year effect & No & No & Yes & Yes \\
Estimation method & No & FE & FE \\
Adj $R^{2}$ & OLS & 0.403 & 0.615 & 0.606 \\
Obs & 0.417 & 390 & 390 & 390 \\
\hline
\end{tabular}

Note. $t$-statistics in parenthesis. ${ }^{* * *} p$ value is less than 0.001 .

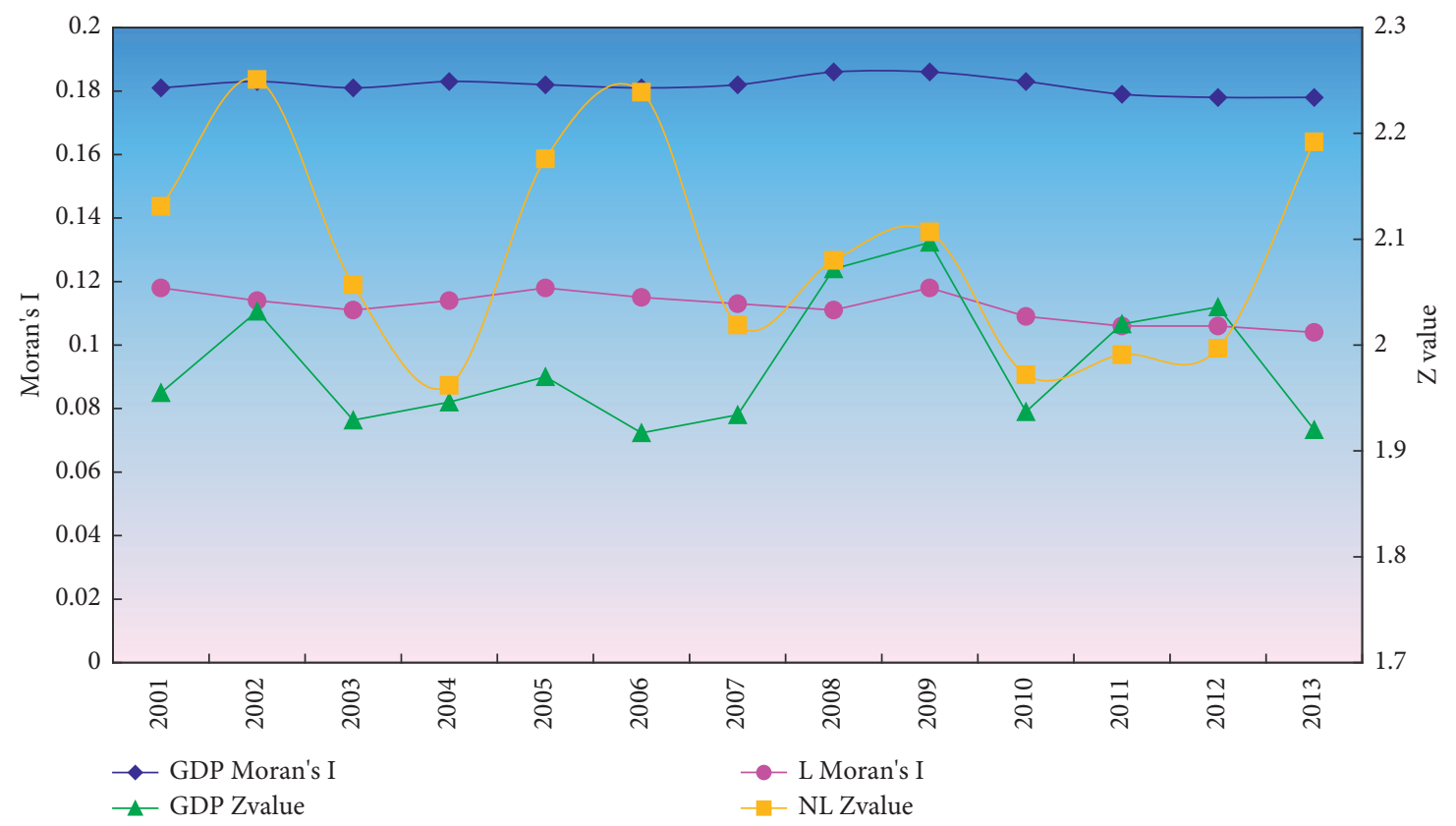

FIgURE 3: Autocorrelation test of China's GDP and nighttime light, 2001-2013.

4.3. Intermediary Effect Test. In this section, we conducted an intermediary effect test on industry-university cooperation, technological innovation, and economic development to determine whether industry-university cooperation affects economic development through technological innovation. The sequential test procedure method was used to investigate the intermediary effect. Figure 4 shows the theoretical model of intermediary effect test. If the parameters $a, b$, and $d$ are significant, the variable technological innovation is an intermediary variable. The FE regression model was used to model (i) to (iii), and the control variables capital input (CI), labor 
TABLE 4: Results of panel unit root test.

\begin{tabular}{|c|c|c|c|c|c|c|}
\hline Variable & & LLC & Breitung t-stat & IPS & ADF-fisher & PP-fisher \\
\hline & Level value & $\begin{array}{c}-13.739 \\
(0.001)\end{array}$ & $\begin{array}{l}-6.926 \\
(0.001)\end{array}$ & $\begin{array}{l}-7.625 \\
(0.001)\end{array}$ & $\begin{array}{c}159.226 \\
(0.001)\end{array}$ & $\begin{array}{c}223.158 \\
(0.001)\end{array}$ \\
\hline $\ln N L$ & First-order difference & $\begin{array}{c}-24.677 \\
(0.001)\end{array}$ & $\begin{array}{c}-17.911 \\
(0.001)\end{array}$ & $\begin{array}{c}-15.754 \\
(0.001)\end{array}$ & $\begin{array}{c}282.863 \\
(0.001)\end{array}$ & $\begin{array}{c}491.801 \\
(0.001)\end{array}$ \\
\hline & Level value & $\begin{array}{c}-14.048 \\
(0.001)\end{array}$ & $\begin{array}{c}-14.048 \\
(0.001)\end{array}$ & $\begin{array}{c}-10.101 \\
(0.001)\end{array}$ & $\begin{array}{c}202.662 \\
(0.001)\end{array}$ & $\begin{array}{c}356.089 \\
(0.001)\end{array}$ \\
\hline $\operatorname{lnIUC}$ & First-order difference & $\begin{array}{c}-25.632 \\
(0.001)\end{array}$ & $\begin{array}{l}-5.491 \\
(0.001)\end{array}$ & $\begin{array}{c}-13.897 \\
(0.001)\end{array}$ & $\begin{array}{c}264.831 \\
(0.001)\end{array}$ & $\begin{array}{c}337.577 \\
(0.001)\end{array}$ \\
\hline $\ln \mathrm{TI}$ & First-order difference & $\begin{array}{c}-13.633 \\
(0.001) \\
-22.522 \\
(0.001)\end{array}$ & $\begin{array}{c}-9.821 \\
(0.001) \\
-21.854 \\
(0.001)\end{array}$ & $\begin{array}{c}-4.630 \\
(0.001) \\
-11.453 \\
(0.001)\end{array}$ & $\begin{array}{c}108.051 \\
(0.001) \\
217.334 \\
(0.001)\end{array}$ & $\begin{array}{c}134.248 \\
(0.001) \\
523.813 \\
(0.001)\end{array}$ \\
\hline
\end{tabular}

Note. $p$-statistics in parenthesis. First generation panel unit root tests without cross-sectional dependence. Second generation panel unit root tests with crosssectional dependence.

TABLE 5: Results of SDM under nighttime light data.

\begin{tabular}{|c|c|c|c|c|c|c|}
\hline Variables & $(9)$ & $(10)$ & $(11)$ & (12) & $(13)$ & $(14)$ \\
\hline Constant & $\begin{array}{c}7.523^{* * *} \\
(9.595)\end{array}$ & & & & & \\
\hline LnIUC & $\begin{array}{c}0.088^{* * *} \\
(3.441)\end{array}$ & $\begin{array}{c}2.534^{* * *} \\
(6.849)\end{array}$ & $\begin{array}{c}0.073^{* *} \\
(2.819)\end{array}$ & $\begin{array}{c}2.624 \\
(8.442)\end{array}$ & $\begin{array}{c}0.344^{* * *} \\
(6.464)\end{array}$ & $\begin{array}{c}0.275^{* * *} \\
(5.631)\end{array}$ \\
\hline LnTI & $\begin{array}{c}0.323^{* * *} \\
(8.983)\end{array}$ & $\begin{array}{c}0.008 \\
(0.405)\end{array}$ & $\begin{array}{c}0.341^{* * *} \\
(9.358)\end{array}$ & $\begin{array}{c}0.022 \\
(1.365)\end{array}$ & $\begin{array}{c}0.023 \\
(1.149)\end{array}$ & $\begin{array}{c}0.233^{* *} \\
(2.546)\end{array}$ \\
\hline LnCI & & & & & $\begin{array}{c}-0.249^{* * *} \\
(-2.635)\end{array}$ & $\begin{array}{c}0.017^{* * *} \\
(10.453)\end{array}$ \\
\hline LnLI & & & & & $\begin{array}{c}0.192^{* * *} \\
(3.204)\end{array}$ & $\begin{array}{c}0.067 \\
(1.057)\end{array}$ \\
\hline LnFI & & & & & $\begin{array}{l}0.320^{*} \\
(2.426)\end{array}$ & $\begin{array}{c}0.089^{* * *} \\
(4.079)\end{array}$ \\
\hline $\ln I \mathrm{UC} \times \ln \mathrm{TI}$ & & & & & & $\begin{array}{c}0.013 \\
(0.843)\end{array}$ \\
\hline $\mathrm{W} * \operatorname{LnIUC}$ & $\begin{array}{c}-0.238^{* * *} \\
(-5.474)\end{array}$ & $\begin{array}{c}-1.726^{* * *} \\
(-4.399)\end{array}$ & $\begin{array}{c}-0.365^{* * *} \\
(-6.033)\end{array}$ & $\begin{array}{c}1.705 \\
(2.828)\end{array}$ & $\begin{array}{c}-2.928^{* * *} \\
(-4.847)\end{array}$ & $\begin{array}{c}-0.045 \\
(-0.348)\end{array}$ \\
\hline $\mathrm{W} * \mathrm{LnTI}$ & $\begin{array}{c}-0.153^{* * * *} \\
(-3.235)\end{array}$ & $\begin{array}{c}0.011 \\
(0.506)\end{array}$ & $\begin{array}{c}0.075 \\
(0.846)\end{array}$ & $\begin{array}{c}0.112 \\
(2.373)\end{array}$ & $\begin{array}{c}-0.010 \\
(-0.463)\end{array}$ & $\begin{array}{l}-0.465^{*} \\
(-2.056)\end{array}$ \\
\hline $\mathrm{W} * \mathrm{LnCI}$ & & & & & $\begin{array}{c}3.602^{* * *} \\
(3.516)\end{array}$ & $\begin{array}{l}-0.749^{*} \\
(-2.200)\end{array}$ \\
\hline $\mathrm{W} * \mathrm{LnLI}$ & & & & & $\begin{array}{c}1.223^{* * *} \\
(9.759)\end{array}$ & $\begin{array}{l}1.495^{* * *} \\
(12.355)\end{array}$ \\
\hline $\mathrm{W} * \mathrm{LnFI}$ & & & & & $\begin{array}{c}-0.068 \\
(-1.873)\end{array}$ & $\begin{array}{c}0.398^{* * *} \\
(4.692)\end{array}$ \\
\hline $\mathrm{W} * \mathrm{IUC} * \mathrm{TI}$ & & & & & & $\begin{array}{c}-0.132^{* * *} \\
(-3.078)\end{array}$ \\
\hline$\rho$ & $\begin{array}{c}0.434^{* * *} \\
(6.801)\end{array}$ & $\begin{array}{c}0.636^{* * *} \\
(13.249)\end{array}$ & $\begin{array}{c}0.299^{* * *} \\
(4.169)\end{array}$ & $\begin{array}{c}-0.218 \\
(-2.445)\end{array}$ & $\begin{array}{l}0.629^{* * *} \\
(13.037)\end{array}$ & $\begin{array}{r}0.645^{* * *} \\
(13.814)\end{array}$ \\
\hline $\log l$ & -304.705 & 338.747 & -291.650 & 411.624 & 348.723 & -139.523 \\
\hline$R^{2}$ & 0.591 & 0.985 & 0.609 & 0.989 & 0.986 & 0.828 \\
\hline Wald-lag & & & & $14.015^{* * *}$ & $40.626^{* * *}$ & $45.692^{* * *}$ \\
\hline LR-lag & & & & $12.673^{* *}$ & $37.729^{* * *}$ & $43.508^{* * *}$ \\
\hline Wald-error & & & & $9.760^{* *}$ & $37.358^{* * *}$ & $45.719^{* * *}$ \\
\hline LR-error & & & & $9.525^{* *}$ & $35.473^{* * *}$ & $43.529^{* * *}$ \\
\hline Hausman & $93.356^{* * *}$ & $67.873^{* * *}$ & $41.698^{* * *}$ & & & \\
\hline
\end{tabular}

Note. $t$-statistics in parenthesis. ${ }^{*} p<0.05,{ }^{* *} p<0.01$, and ${ }^{* * *} p<0.001$. 
TABLE 6: Results of spillover effect decomposition.

\begin{tabular}{lccc}
\hline Variables & Direct effect & Spillover effect & Total effect \\
\hline LnIUC & $0.053^{* *}(0.038)$ & $-0.475^{* * *}(0.001)$ & $-0.422^{* * *}(0.001)$ \\
LnTI & $0.351^{* * *}(0.001)$ & $0.247^{* *}(0.047)$ & $0.598^{* * *}(0.001)$ \\
\hline
\end{tabular}

Note. $p$-statistics in parenthesis. ${ }^{*} p<0.1,{ }^{* *} p<0.05$, and ${ }^{* * *} p<0.01$.

TABLE 7: Results of SDM model under GDP data.

\begin{tabular}{|c|c|c|c|c|c|c|}
\hline Variables & $(15)$ & (16) & $(17)$ & (18) & (19) & $(20)$ \\
\hline Constant & $\begin{array}{c}2.283^{* * *} \\
(7.639)\end{array}$ & & & & & \\
\hline LnIUC & $\begin{array}{c}0.077^{* * * *} \\
(4.392)\end{array}$ & $\begin{array}{c}0.855^{* * *} \\
(4.376)\end{array}$ & $\begin{array}{c}0.058^{* * *} \\
(3.350)\end{array}$ & $\begin{array}{c}0.636^{* * *} \\
(3.714)\end{array}$ & $\begin{array}{c}0.054^{* * *} \\
(4.815)\end{array}$ & $\begin{array}{c}0.069^{* * *} \\
(3.648)\end{array}$ \\
\hline LnTI & $\begin{array}{l}0.569^{* * *} \\
(22.808)\end{array}$ & $\begin{array}{c}0.009 \\
(0.863)\end{array}$ & $\begin{array}{l}0.582^{* * *} \\
(23.699)\end{array}$ & $\begin{array}{c}0.005 \\
(0.545)\end{array}$ & $\begin{array}{c}0.064^{* *} \\
(2.918)\end{array}$ & $\begin{array}{c}0.143^{* * *} \\
(4.354)\end{array}$ \\
\hline $\mathrm{LnCI}$ & & & & & $\begin{array}{l}0.733^{* * *} \\
(17.094)\end{array}$ & $\begin{array}{l}0.782^{* * *} \\
(20.087)\end{array}$ \\
\hline LnLI & & & & & $\begin{array}{c}0.327^{* * *} \\
(13.749)\end{array}$ & $\begin{array}{c}0.220^{* * *} \\
(10.925)\end{array}$ \\
\hline LnFI & & & & & $\begin{array}{c}-0.273^{* * *} \\
(-10.033)\end{array}$ & $\begin{array}{c}-0.125^{* * *} \\
(-5.851)\end{array}$ \\
\hline $\ln I U C \times \ln T I$ & & & & & & $\begin{array}{l}-0.006^{*} \\
(-2.412)\end{array}$ \\
\hline $\mathrm{W}^{*}$ LnIUC & $\begin{array}{c}-0.117^{* * *} \\
(-3.880)\end{array}$ & $\begin{array}{c}-0.289 \\
(-1.347)\end{array}$ & $\begin{array}{c}-0.246^{* * *} \\
(-6.034)\end{array}$ & $\begin{array}{c}-1.674^{* * *} \\
(-5.655)\end{array}$ & $\begin{array}{c}-0.047 \\
(-1.907)\end{array}$ & $\begin{array}{l}-0.094^{*} \\
(-2.065)\end{array}$ \\
\hline $\mathrm{W}^{*} \operatorname{LnTI}$ & $\begin{array}{c}-0.435^{* * *} \\
(-12.361)\end{array}$ & $\begin{array}{c}-0.00 \\
(-0.622)\end{array}$ & $\begin{array}{c}0.010 \\
(0.131)\end{array}$ & $\begin{array}{c}0.030 \\
(1.165)\end{array}$ & $\begin{array}{c}-0.079 \\
(-1.124)\end{array}$ & $\begin{array}{c}0.029 \\
(0.352)\end{array}$ \\
\hline $\mathrm{W}^{*} \mathrm{LnCI}$ & & & & & $\begin{array}{l}-0.152^{* *} \\
(-2.666)\end{array}$ & $\begin{array}{c}0.926^{* * *} \\
(8.146)\end{array}$ \\
\hline $\mathrm{W}^{*} \operatorname{LnLI}$ & & & & & $\begin{array}{c}0.568^{* * *} \\
(3.827)\end{array}$ & $\begin{array}{c}-0.233^{* * *} \\
(-6.524)\end{array}$ \\
\hline $\mathrm{W}^{*} \mathrm{LnFI}$ & & & & & $\begin{array}{c}0.287^{* * *} \\
(4.696)\end{array}$ & $\begin{array}{l}0.130^{*} \\
(2.412)\end{array}$ \\
\hline $\mathrm{W}^{*} \mathrm{IUC}^{*} \mathrm{TI}$ & & & & & & $\begin{array}{c}-0.007 \\
(-1.235)\end{array}$ \\
\hline$\rho$ & $\begin{array}{c}0.650^{* * *} \\
(14.103)\end{array}$ & $\begin{array}{l}0.848^{* * *} \\
(36.935)\end{array}$ & $\begin{array}{c}0.144 \\
(1.838)\end{array}$ & $\begin{array}{c}-0.024 \\
(-0.278)\end{array}$ & $\begin{array}{c}-0.008 \\
(-0.098)\end{array}$ & $\begin{array}{c}-0.136 \\
(-1.827)\end{array}$ \\
\hline $\log l$ & -171.811 & 567.503 & -135.835 & 648.146 & 171.362 & 246.640 \\
\hline$R^{2}$ & 0.875 & 0.997 & 0.886 & 0.998 & 0.971 & 0.984 \\
\hline Wald-lag & & & & $32.559^{* * *}$ & $51.902^{* * *}$ & $179.391^{* * *}$ \\
\hline LR-lag & & & & $31.384^{* * *}$ & $48.688^{* * *}$ & $149.867^{* * *}$ \\
\hline Wald-error & & & & $30.750^{* * *}$ & $49.706^{* * *}$ & $321.430^{* * *}$ \\
\hline LR-error & & & & $31.345^{* * *}$ & $48.700^{* * *}$ & $235.051^{* * *}$ \\
\hline Hausman & $29.788^{* *}$ & $28.471^{* *}$ & $32.221^{* * *}$ & & & \\
\hline
\end{tabular}

Note. $t$-statistics in parenthesis. ${ }^{*} p<0.05,{ }^{* *} p<0.01$, and ${ }^{* * *} p<0.001$.
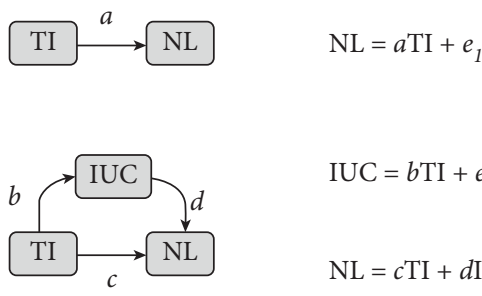

$$
\begin{aligned}
& \mathrm{IUC}=b \mathrm{TI}+e_{2} \\
& \mathrm{NL}=c \mathrm{TI}+d \mathrm{IUC}+e_{3}
\end{aligned}
$$

FIGURE 4: Theoretical model of intermediary effect test.

input (LI), and foreign investment (FI) were added for comparative analysis. The regression results are shown in Table 8.
Without control variables, parameters $a=2.538$ $(p \leq 0.001, \quad t=45.515), \quad b=7.158 \quad(p \leq 0.001, \quad t=24.496)$, $c=2.261 \quad(p \leq 0.001, t=25.295)$, and $d=0.039(p \leq 0.001$, $t=3.927$ ) were all significant at the $1 \%$ level, indicating that technological innovation was an intermediary variable, and the intermediary effect was significant. With control variables, parameters $a=1.389 \quad(p \leq 0.001, \quad t=4.559), \quad b=-3.207$ $(p \leq 0.001, t=-2.087), c=1.482(p \leq 0.001, t=4.882)$, and $d=0.029(p \leq 0.001, t=2.800)$ all passed the $5 \%$ significance level, indicating that after adding the control variables capital input (CI), labor input (LI), and foreign investment (FI), parameters $a, b$, and $d$ were still significant, which further suggests that industry-university cooperation affect China's economic development through technological innovation. 
TABLE 8: Regression results of intermediate equation.

\begin{tabular}{|c|c|c|c|c|c|c|}
\hline \multirow{2}{*}{ Explanatory variables } & \multicolumn{6}{|c|}{ Explained variable } \\
\hline & $\operatorname{lnNL}$ & $\operatorname{LnTI}$ & $\operatorname{lnNL}$ & $\operatorname{lnNL}$ & $\operatorname{LnTI}$ & $\operatorname{lnNL}$ \\
\hline $\operatorname{lnIUC}$ & $\begin{array}{l}2.538^{* * *} \\
(45.515)\end{array}$ & $\begin{array}{l}7.158^{* * *} \\
(24.496)\end{array}$ & $\begin{array}{l}2.261^{* * *} \\
(25.295)\end{array}$ & $\begin{array}{c}1.389^{* * *} \\
(4.559)\end{array}$ & $\begin{array}{l}-3.207^{*} \\
(-2.087)\end{array}$ & $\begin{array}{c}1.482^{* * *} \\
(4.882)\end{array}$ \\
\hline LnTI & & & $\begin{array}{c}0.039^{* * *} \\
(3.927)\end{array}$ & & & $\begin{array}{c}0.029^{* *} \\
(2.800)\end{array}$ \\
\hline$R^{2}$ & 0.974 & 0.839 & 0.975 & 0.975 & 0.857 & 0.976 \\
\hline Log likelihood & 255.673 & -390.221 & 263.898 & 265.777 & -365.187 & 270.038 \\
\hline Control variable & No & No & No & Yes & Yes & Yes \\
\hline Method & $\mathrm{FE}$ & $\mathrm{FE}$ & $\mathrm{FE}$ & $\mathrm{FE}$ & $\mathrm{FE}$ & FE \\
\hline
\end{tabular}

Note. $t$-statistics in parenthesis. ${ }^{*} p<0.05,{ }^{* *} p<0.01$, and ${ }^{* * *} p<0.001$.

\section{Conclusions and Policy Implications}

Using the spatial autocorrelation, panel unit root test, and spatial measurement model, the relationship between China's industry-university cooperation and economic development was empirically investigated. The main conclusions of this study are as follows.

First, the nighttime light could be used as a proxy variable for GDP. There was a significant positive correlation between GDP and nighttime light. GDP and nighttime light showed basically the same spatial autocorrelation.

Second, industry-university cooperation was associated with economic development. There is an interaction between industry-university cooperation and technological innovation, but it is not significant. Technological innovation was an intermediary variable and industry-university cooperation affect China's economic development through technological innovation.

Employing the results in Section 4, we proposed three policy implications to improve regional economic development.

First, the government should optimize the technological innovation environment. To this end, it can be expanded from three aspects: (1) encouraging enterprises, universities, and research institutions to jointly carry out technological innovation activities; (2) improving the technology innovation system and promoting the transfer of innovation achievements; and (3) encouraging enterprises to carry out scientific and technological innovation activities by streamlining administration and delegating power.

Second, the government should improve the quality of industry-university cooperation. The government can use preferential policies to guide in-depth industry-university cooperation. The government should standardize and optimize the cooperation model between universities, enterprises, and research institutions, improve the common management of research funds, and strengthen the sharing of interests and risks.

Third, the government should pay attention to the collaborative innovation development of industry, university, and research institute. The government can improve the intellectual property protection system, standardize the operation of the technical knowledge market, and promote the effective use of collaborative innovation by industry, universities, and research institutions.

\section{Data Availability}

The data used to support the findings of this study are available from the corresponding author upon request.

\section{Conflicts of Interest}

The authors declare that there are no conflicts of interest regarding the publication of this paper.

\section{Acknowledgments}

This work was supported by Major Program of National Fund of Philosophy and Social Science of China (20ZDA092).

\section{References}

[1] Z. Wang and Y. Zhu, "Do energy technology innovations contribute to $\mathrm{CO} 2$ emissions abatement? a spatial perspective," The Science of the Total Environment, vol. 726, Article ID 138574, 2020.

[2] J. Abbas and M. Sağsan, "Impact of knowledge management practices on green innovation and corporate sustainable development: a structural analysis," Journal of Cleaner Production, vol. 229, pp. 611-620, 2019.

[3] L. Gori and M. Sodini, "Endogenous labour supply, endogenous lifetime and economic development," Structural Change and Economic Dynamics, vol. 52, pp. 238-259, 2020.

[4] Y. Suh, C. Woo, J. Koh, and J. Jeon, "A," Technological Forecasting and Social Change, vol. 148, Article ID 119740, 2019.

[5] H.-F. Lu, "Enhancing university student employability through practical experiential learning in the sport industry: an industry-academia cooperation case from Taiwan," Journal of Hospitality, Leisure, Sports and Tourism Education, vol. 28, Article ID 100301, 2021.

[6] C. N. P. s. Congress, "The report of the 18th national congress," in Proceedings of the 18th National Congress, Beijing, China, November 2012.

[7] O. Movshuk, "The reliability of China's growth figures: a survey of recent statistical controversies," Journal of Econometric Study of Northeast Asia, vol. 27, no. 1, pp. 31-45, 2002.

[8] G. Ji, L. Tian, J. Zhao, Y. Yue, and Z. Wang, "Detecting spatiotemporal dynamics of PM2.5 emission data in China using DMSP-OLS nighttime stable light data," Journal of Cleaner Production, vol. 209, pp. 363-370, 2019. 
[9] P. Kumar, H. Sajjad, P. K. Joshi et al., "Modeling the luminous intensity of beijing, China using dmsp-ols night-time lights series data for estimating population density," Physics and Chemistry of the Earth, Parts A/B/C, vol. 109, pp. 31-39, 2019.

[10] Q. Lv, H. Liu, J. Wang, H. Liu, and Y. Shang, "Multiscale analysis on spatiotemporal dynamics of energy consumption co2 emissions in China: utilizing the integrated of dmsp-ols and npp-viirs nighttime light datasets," The Science of the Total Environment, vol. 703, Article ID 134394, 2020.

[11] M. M. Bennett and L. C. Smith, "Using multitemporal nighttime lights data to compare regional development in Russia and China, 1992-2012," International Journal of Remote Sensing, vol. 38, no. 21, pp. 5962-5991, 2017.

[12] N. Zhao, N. Currit, and E. Samson, "Net primary production and gross domestic product in China derived from satellite imagery," Ecological Economics, vol. 70, no. 5, pp. 921-928, 2011.

[13] P. Propastin and M. Kappas, "Assessing satellite-observed nighttime lights for monitoring socioeconomic parameters in the republic of Kazakhstan," GIScience \& Remote Sensing, vol. 49, no. 4, pp. 538-557, 2012.

[14] X. Zhu, M. Ma, H. Yang, and W. Ge, "Modeling the spatiotemporal dynamics of gross domestic product in China using extended temporal coverage nighttime light data," Remote Sensing, vol. 9, no. 6, p. 626, 2017.

[15] C. Li, G. Li, Y. Zhu, Y. Ge, H.-t. Kung, and Y. Wu, "A likelihood-based spatial statistical transformation model (LBSSTM) of regional economic development using DMSP/ OLS time-series nighttime light imagery," Spatial Statistics, vol. 21, pp. 421-439, 2017.

[16] X. Jin, X. Li, Z. Feng, J. Wu, and K. Wu, "Linking ecological efficiency and the economic agglomeration of China based on the ecological footprint and nighttime light data," Ecological Indicators, vol. 111, Article ID 106035, 2020.

[17] J. Kang, J. Lee, D. Jang, and S. Park, "A methodology of partner selection for sustainable industry-university cooperation based on lda topic model," Sustainability, vol. 11, no. 12, pp. 1-16, 2019.

[18] Y. Xu and N. Jin, "A study of the impact of university-industry-goverbment cooperation on regiomal economic growth," Science Research Management, vol. 31, no. 1, pp. 147-152, 2010.

[19] H. Hamdan, F. Yusof, D. Omar, F. Abdullah, N. Nasrudin, and I. Abullah, "University industrial linkages: relationship towards economic growth and development in Malaysia," World Academy of Science, Engineering \& Technology, vol. 5, no. 10, pp. 1284-1291, 2011.

[20] Y. Wu, J. Zhao, and Y. Wang, "Researches on economic growth performance of industry-university-research institution collaboration and its interpretation," Science Research Management, vol. 35, no. 7, pp. 147-153, 2014.

[21] L. Lv and D. Kan, "Empirical study on the impact of industryuniversity-research cooperative innovation on economic growth:taking jiangxi province as an example," Science and Technology Management Research, vol. 23, pp. 130-135, 2017.

[22] G. Castañeda and O. A. Guerrero, "The resilience of public policies in economic development," Complexity, vol. 2018, Article ID 9672849, 15 pages, 2018.

[23] A. Dhrifi, "Foreign direct investment, technological innovation and economic growth: empirical evidence using simultaneous equations model," International Review of Economics, vol. 62, no. 4, pp. 381-400, 2015.

[24] V. H. Torres-Preciado, M. Polanco-Gaytán, and M. Á. TinocoZermeño, "Technological innovation and regional economic growth in Mexico: a spatial perspective," The Annals of Regional Science, vol. 52, no. 1, pp. 183-200, 2014.

[25] Y. Song, J. Zhang, Y. Song, X. Fan, Y. Zhu, and Z. Chen, "Can industry-university-research collaborative innovation efficiency reduce carbon emissions?” Technological Forecasting and Social Change, vol. 157, Article ID 120094, 2020.

[26] J. Luo, A. L. Olechowski, and C. L. Magee, "Technology-based design and sustainable economic growth," Technovation, vol. 34, no. 11, pp. 663-677, 2014.

[27] S. Wei, Y. Wang, and T. Danning, "The impacts of industryuniversity-research institute's collaboration on the innovative performance of the Chinese high-tech industries," Business Management Journal, vol. 35, no. 5, pp. 19-30, 2013.

[28] Y. Zhu, Z. Wang, J. Yang, and L. Zhu, "Does renewable energy technological innovation control China's air pollution? A spatial analysis," Journal of Cleaner Production, vol. 250, Article ID 119515, 2020.

[29] Y. Zhu, Z. Wang, S. Qiu, and L. Zhu, "Effects of environmental regulations on technological innovation efficiency in China's industrial enterprises: a spatial analysis," Sustainability, vol. 11, pp. 1-19, 2019.

[30] Z. Lv and S. Li, "How financial development affects $\mathrm{CO} 2$ emissions: a spatial econometric analysis," Journal of Environmental Management, vol. 277, Article ID 111397, 2021.

[31] W. Chen, R. He, and Q. Wu, "A novel efficiency measure model for industrial land use based on subvector data envelope analysis and spatial analysis method," Complexity, vol. 2017, Article ID 9516267, 11 pages, 2017.

[32] S. Chen, D. Zhuang, and H. Zhang, "GIS-based spatial autocorrelation analysis of housing prices oriented towards a view of spatiotemporal homogeneity and nonstationarity: a case study of guangzhou, China," Complexity, vol. 2020, Article ID 1079024, 16 pages, 2020.

[33] Y. Cao, N. Wan, H. Zhang, X. Zhang, and Q. Zhu, "Linking environmental regulation and economic growth through technological innovation and resourceconsumption: analysis of spatial interaction patterns of urban agglomerations," Ecological Indicators, vol. 112, Article ID 106062, 2020.

[34] C. N. Mensah, X. Long, L. Dauda et al., "Technological innovation and green growth in the organization for economic cooperation and development economies," Journal of Cleaner Production, vol. 240, Article ID 118204, 2019.

[35] A. Omri, "Technological innovation and sustainable development: does the stage of development matter?" Environmental Impact Assessment Review, vol. 83, Article ID 106398, 2020.

[36] B. Xu, J. Sendra-García, Y. Gao, and X. Chen, "Driving total factor productivity: capital and labor with tax allocation," Technological Forecasting and Social Change, vol. 150, Article ID 119782, 2020.

[37] D. Lo, F. Hong, and G. Li, "Assessing the role of inward foreign direct investment in Chinese economic development, 1990-2007: towards a synthesis of alternative views," Structural Change and Economic Dynamics, vol. 37, pp. 107-120, 2016. 